\section{Orchard Heating in the United States.}

MUCH progress has been made of late years in the study of fruit growing, especially with reference to orchard heating and the development of more accurate methods of predicting low temperatures and counteracting their damaging effects. Special information has been given in the U.S. Monthly Weather Review for different districts, notably for North Carolina, in Supplement No. I9, published last year; and the Monthly Weather Review for December last has an article on "Damaging Temperatures and Orchard Heating in the Rogue River Valley, Oregon," by Mr. F. D. Young, Meteorologist, and Mr. C. C. Cate, Plant Pathologist. Observations made in the past with regard to temperature are utilised by the authors.

The pear is the principal fruit crop of the valley, but so far less has been done in determining the damage by cold to this crop than to peaches, apples, and apricots. A large part of the article deals with the actual comparisons of the pear crops harvested from adjoining protected and unprotected orchards during the seasons of I92I and I922, and partially with 1923. The cold due to radiation with a clear sky is the special lowering of temperature dealt with. The upper and less protected parts of the tree feel the effect of radiation more fully. Fruit blossoms were examined and the extent of damage noted for the different exposures under examination, and from 150 to 350 blossoms were cut open and examined in determining percentages of damage at each count. The protected orchard is equipped with a various number of oil-heaters, ranging from about 9 to 250 2-gallon lard-pails to the acre. Graphs are given showing the range of temperature at unheated check stations and at heated orchards, the heating, in examples shown, making a difference of $4^{\circ}$ to $8^{\circ} \mathrm{F}$. The great value is clearly the maintenance of night temperature above the damaging point, say above about $30^{\circ} \mathrm{F}$.

Excellent photographs are given showing the development of pear blossoms and fruit at different dates of progress, and of fruit in which the seeds have been damaged or undamaged by frost. Photographs also show the crop, in number of pears at different heights on the tree; for example-ground to $6 \mathrm{ft}$., 6-IO ft., IO-I4 ft., and above. Also the cropping in boxes from respective trees in protected and unprotected orchards-ranging from more than 20 boxes to a single box-is given.

In one of the largest pear and apple orchards in the Rogue River Valley, orchard heaters have been used during the past thirteen years, and during that time the fruit crop has never been materially reduced through frost-damage. A rougher method of orchard heating was previously adopted, but it was far less efficacious.

Although the discussion under review deals only with the Rogue River Valley, it is stated that the effectiveness of orchard heating, where properly handled, applies with equal force in preventing damage by frost in Western Oregon and in the entire States of California and Washington. Detailed studies in southern California show that orange groves can be protected against outside temperatures of $18^{\circ} \mathrm{F}$., and the protective value of heating is generally accepted by citrus growers throughout the State.

The economic phase of orchard heating has been intentionally ignored, although the authors give a few convincing facts in support of the cost incurred, and they note that, in the Pacific Coast States, orchard heating is generally practised only in the colder portions of each district.

$$
\text { NO. } 2862 \text {, vOL. I I } 4 \text { ] }
$$

\section{University and Educational Intelligence.}

LoNDON.-Applications are invited for the William Julius Mickle fellowship of the value of at least 2ool., to be awarded to the man or woman who, being resident in London, and a graduate of the University, has in the opinion of the Senate done most to advance medical art or science during the preceding five years. Applications must be received before October I next. Particulars may be obtained on application to the Academic Registrar, University of London, South Kensington, S.W.7.

The University of the Witwatersrand, Johannesburg, gives in its Calendar for $\mathrm{I} 924$ an interesting sketch of its origin and development. From 1916, when the Witwatersrand University Committee was formed for the purpose of developing the South African School of Mines and Technology, first into a full University College and ultimately into a University, progress has been very rapid, the number of students in each of the years I916 to I923 having been : 77, I73, 191, 301, 635, 812, 983, I106. The University, formally opened in October 1922, has now fully organised Faculties of Arts, Science, Medicine, Commerce, Engineering, and Law, and a teaching staff of a hundred professors and lecturers.

The United States National Research Council has published in Bulletin No. 38 , particulars of more than 400 foundations of fellowships and scholarships for advanced work in science and technology. The compilation is provided with a subject index which shows that about 170 foundations are for research in pure science, I40 for research in technology, and 65 for medical research. A comparison with Appendix xxiv. of the British Empire Universities Yearbook seems to show that it is a much commoner practice among American than among British universities to admit to candidature graduates of institutions other than those in which the fellowships, etc., are tenable. The practice has obvious advantages, especially in the case of a university which has achieved pre-eminence in the advanced teaching, or facilities for the advanced study of, one or more branches of knowledge. From one point of view it is complementary to the practice of giving travelling fellowships.

AN Education Week is being organised for November $I_{7-23}$ by the United States Bureau of Education in co-operation with the National Education Association (representing the school teachers of the United States) and the American Legion. The celebrations are to be distributed over the week thus: Monday, Constitution Day - "The Constitution : the bulwark of democracy and happiness "; Tuesday, Patriotism Day-" The United States flag is the living symbol of the ideals and institutions of our republic"; Wednesday, School and Teacher Day-" The teacher: the guiding influence of future America " ; Thursday, Illiteracy Day - " Informed intelligence is the foundation of representative government" ; Friday, Physical Education Day_- "Playgrounds and athletic fields mean a strong healthy nation"; Saturday, Community Day- "Service to Community, State, and Nation is the duty of every citizen " ; Sunday, For God and Country Day-" Religion,' Morality, and Education are necessary for good government." For each day, appropriate topics and slogans are suggested. Conspicuous among those for the first two days are the following: Revolutionists, communists, and extreme pacifists are a menace to our constitution's guarantees of life, liberty, justice, security, and opportunity; the red flag means death, destruction, poverty, starvation, disease, anarchy, and dictatorship ; stamp out revolutionary radicalism. 